\title{
POÉTICAS DA DIFERENÇA: A REPRESENTAÇÃO DE SI NA LÍRICA AFRO- FEMININA
}

\author{
Lívia Maria Natália de Souza Santos ${ }^{1}$
}

\begin{abstract}
Resumo: Este artigo se propõe a pensar a literatura afro-feminina como instituidora de uma rasura teórica necessária no campo da teoria da literatura.

Palavras-Chave: Rasura; Literatura afro-feminina; Teoria da literatura.
\end{abstract}

\begin{abstract}
This paper proposes to think the literature african-female of an erasure necessary theoretical field of Literary Theory.

Keywords: Erasure; Female African Literature; Literary Theory.
\end{abstract}

\section{INTRODUÇÃO}

A construção do lugar do subalternizado é uma rede profícua de silenciamentos e projeções que se pauta pela negação e sistemático apagamento da diferença pelo discurso hegemônico. Ao negar a existência de qualquer inflexão que inferiorize o outro em seu discurso, e, ato continuum, projetar tal comportamento a um terceiro, escondido sob a malha insondável do anônimo, excepcional e problemático, engendra-se um lavar as mãos que gera um lugar de conforto que não apenas adia uma reflexão mais firme sobre o problema, mas também coloca em suspenso a possibilidade de denunciar, na omissão, um contributo para a manutenção das diferenças rebaixadoras. Ao negar racismos, sexismos, homofobias ou qualquer outro temor ou terror às alteridades, há uma sistemática desmobilização da necessidade de afirmar a diferença enquanto valor e uma conseqüente negação de acesso a bens simbólicos, e até pecuniários.

As Ciências Humanas, instauradas no horizonte de formação ideológico como sendo uma forma de sistematização de saberes elaborando uma via mais eficiente de compreensão da travessia humana, não se responsabilizou por franquear a humanidade de maneira irrestrita a todos os sujeitos. Foi justamente o campo validado e preenchido de autoridade das ciências

1 Professora Adjunta de Teoria da Literatura do Departamento de Fundamentos para o Estudo das Letras, no Instituto de Letras da Universidade Federal da Bahia (UFBA), em Salvador; Doutora em Teorias e Crítica da Literatura e da Cultura pela mesma IES; Líder do projeto de pesquisa Corpus Dissidente: Poéticas da Subalternidade em Escritas e Estéticas da Diferença; poeta, autora do livro "Água Negra” (Prêmio Banco Capital de Poesia, 2011). Endereço eletrônico: livianataliass@gmail.com. 
que mais constantemente se ocupou de forjar argumentos que ratificassem a degenerescência do negro, a fragilidade da mulher, a limitação cognitiva do índio e a anormalidade doentia dos homossexuais, dentre outras representações. O campo das representações sempre será atravessado por um déficit, pois não dá conta do lugar deste outro que é narrado. Desta forma, mais que pensar a cultura enquanto uma linguagem, uma representação em plenitude da alteridade, pode-se potencializar a análise dos objetos culturais pensando-os em sua dimensão política, seja através do que dele escapa, seja através do que ele se interessa em abarcar, como nos aponta Stuart Hall (2003).

Os pudores que atravessam a exploração dos objetos estéticos, principalmente os literários, que formulem ilações entre o labor artístico e um discurso eticamente posicionado, tem feito dos Estudos Literários uma espécie de Hidra de cuja cabeça imortal nunca será extirpada. Ou seja, não há espaço para a instauração de reflexões que atualizem o campo deslocando a atenção de nossos estudos dos textos que canônicos ou que se comportem como tal: corta-se o pescoço da Hidra e, do mesmo sangue, da mesma ferida nasce uma cabeça que se limita a reproduzir a anterior. Esta forma de produção de conhecimento no campo dos Estudos Literários, com destaque para a Teoria da Literatura, finda por formular a sensação desta disciplina como sendo uma grande mãe que a todos abarca, negando a possibilidade de pensar a produção literária a partir da inscrição de diferenças várias, nega-se a possibilidade de pensar a literatura através do recorte desta diferença, obliterando os vários sobrenomes que ela pode ter como forma de potencializar o campo e desenvolver outros critérios e percursos de estudos.

A ilusão de abarcar a totalidade que atravessou todas as ciências, instaurou um corte profundo na Teoria da Literatura através da deliberada crença, ainda Moderna, de que ou haveria a alta literatura ou literatura nenhuma. Neste ínterim, a formação dos critérios de seleção e atribuição de valor literário concentrou-se na valoração estética como se este fosse um padrão isento de juízo de valor. Não é impossível que esta forma de compreender a literatura tenha sido engendrada por uma ilusão de que o discurso literário, sublime que é, estaria fora do poder: "Essa trapaça salutar, essa esquiva, esse logro magnífico que permite ouvir a língua fora do poder, no esplendor de uma revolução permanente da linguagem, eu a chamo, quanto a mim: literatura" (BARTHES, 1988). O que se pode destacar da fala de Roland Barthes, mais que a idéia problemática de que a literatura é um lugar "fora do poder" - idéia que foi, mais tarde, discutida e desloca106 Número temático: Literatura, cultura e memória negra. A Cor das Letras - UEFS, n. 12, 2011 
da por Stuart Hall e Michel Foucault, dentre outros - é compreender o caráter insular e relativo instaurado pelo "quanto a mim". Abrir mão do desconforto de pensar o nosso próprio "quanto a mim", elidindo-o da posição de Barthes, tem nos gerado, certamente, algumas limitações e até desinteresse de análise.

Neste sentido, quando afirma que "não há lugar fora do poder", Foucault (1992) igualmente adota um lugar de fala, assumindo, como Roland Barthes, as potências e problemas derivados desta escolha. No nosso investimento de leitura faremos da posição de Foucault um utensílio, tal como o derridiano $(2002,2005)$, no interesse de formular uma reflexão sobre como a Teoria da Literatura pode propor-se a pensar as relações entre literatura e poder prioritariamente no caso daquilo que aqui, a partir da chancela de Geni Guimarães ${ }^{2}$ (escritora negra, ganhadora do prêmio Jabuti), passo a chamar de escrita afro-feminina brasileira.

\section{A TEORIA DA LITERATURA: A DIFERENÇA COMO O LIMITE DO CAMPO}

Um dos compromissos mais relevantes da Teoria da Literatura é o investimento em instrumental analítico para que se torne capaz de dar conta do campo de estudos do qual participa e que, contemporaneamente, tem alargado as suas fronteiras buscando abarcar as escritas antes pensadas como desimportantes. O engessamento do viés de análise da Teoria no estreito horizonte do cânone e da instituição de características exclusivas daquilo que seria o texto literário, retira de seu âmbito de ação a convivência com a literatura que ferve nos mais variados espaços em pleno movimento de desrecalque e ocupação da cena deixando aos Estudos Culturais um campo de trabalho do qual a Teoria da Literatura deveria compartilhar. O alimento das dimensões oceânicas de uma área de estudo, que a tudo seria capaz de abarcar deixando de fora apenas o inadequado, aquilo tradicionalmente pensado como "não-literatura" engendra uma posição pretensiosa uma vez que não se sustenta diante da reconfiguração das formas, temas, contextos de exposição de texto e métodos de escrita que hoje vigoram na literatura.

Não é um dado novo o fato de que os centros epistemológicos sobre os quais se ordenam os saberes nas sociedades ocidentais adentraram, há mais de meio-século, numa poderosa crise de paradigmas. Este caminho de discussão é o mais eficiente pela rapidez do óbvio: concordemos ou não,

2 Anotações do debate promovido no Congresso Mulher e Literatura, 2011. 
todos sabemos do que se trata quando a reflexão entra pelo campo da pósmodernidade. Optarei aqui, no entanto, pelo caminho menos linear, mas, neste momento, mais potente, sem abandonar, no entanto, a contigüidade que as idéias aqui expostas mantém com Canclini, Hall, Huyssen e outros pensadores do pós-moderno.

Interessa aqui abordar não apenas a crise das representações (que nos conduz de maneira imediata para discussão da incapacidade de uma sociedade pequeno-burguesa, calcada em arquétipos falocêntricos, teocêntricos e etnocêntricos gerenciar a emergência das dissonâncias, daquilo que poderíamos pensar como uma demanda não representável, na cena apaziguada dos padrões sociais, culturais e morais), mas, prioritariamente, a problemática da noção de representação.

O berço da idéia de representação está na filosofia grega, a partir do pensamento aristotélico que, num investimento de repensar a problemática relação de Platão com a literatura, instaura o conceito de arte mimética, imitativa não do mundo conforme ele é - pautando-se na noção de uma realidade referencial - mas no seu universo imaginário, explorando as potencialidades do acontecimento. As leituras subseqüentes do filósofo grego fundaram a noção de uma arte representativa que colada estaria à realidade, instauram-se então movimentos dissonantes que perpassaram desde a pintura, com a arte surrealista, por exemplo; passando pela literatura fantástica e pelo realismo mágico até a música indeterminada, regida pelo princípio da descontinuidade.

A leitura de uma arte potencialmente imitativa dialoga com as formas de compreensão do mundo como analisada por Michel Foucault em Nietzsche, Freud e Marx (2005), como sendo um poderoso movimento de naturalização e dissimulação de interpretações nascidas de um jogo de similitudes que ordenam o mundo pelas aparências sonantes, relegando, com o apoio do cristianismo, a dissonância e a diferença para a dimensão demoníaca e inferior das coisas. Ordenada pelas aparências, a lógica das similitudes produz uma sensação de profundidade pelos poderes de construção de verdade que sobre ela age. Assim, a leitura do mundo feita pelo ocidente calca-se na construção de uma interioridade para as coisas, pessoas e conceitos, neste movimento, as noções de conteúdo, verdade e história agem como forças de produção de conhecimento sobre os sujeitos, provocando a sensação de profundidade que vem colada à ilusão de validade e verdade. O mundo representativo-mimético se organiza, então, a partir da invenção de paradigmas que mensuram o valor que cada elemento possui na ordem hierárquica que rege as mais mínimas relações. 
Quando se coloca em suspenso a própria noção de possibilidade de representação, a provocação se dá na direção de compreender que para além das sombras que se projetam para os homens na Caverna de Platão, nada mais há. Não há a carne que sustente a sombra do conceito, ou do ser, ou das instituições. Os valores se sustentam na projeção de uma profundidade em um universo onde tudo é mera superfície. Ou, segundo Derrida (2002), a construção da interioridade e das autoridades dos lugares sociais se dá pelo discurso, como não se questiona a dimensão do discurso como artifício, jogo e formulação de centramentos hierárquicos, ele vira cena de privilégio de instauração de conceitos fechados e ordenadores das diferenças a partir do eixo excludente da identidade.

O abalo promovido nos paradigmas que sustentaram o ideário e as representações do mundo ocidental atravessou discursos variados tendo uma potência rizomática (DELEUZE, 1995) de uma idéia que tem múltiplos nascedouros, passando pela revisão da história, pelo questionamento da representação verossímil, pela constatação da preponderância do inconsciente na psicanálise, pela revisão das concepções de linguagem e emergência dos movimentos sociais que reivindicam, como o maio de 64 na frança, a militância contra ditadura no Brasil ou, mais contemporaneamente, a marcha da maconha, das vadias e a parada gay, o simples direito de gerenciar o corpo como uma posse do sujeito, não como uma segunda casa da divindade, como objeto das múltiplas formas de exercício do biopoder (FOUCAULT, 2008) ou como um campo de aplicação dos limites das sociedades capitalistas e etnocêntricas de base patriarcal.

O que se discute aqui é que, mais que o texto, o corpo produtor do discurso mudou e, muitas vezes, ele irá usar este corpo, antes invisibilizado pelo desejo do outro, como textualidade suplementar, como fundamento polifônico do texto que demanda para si um lugar de interpretação. A compreensão da literatura como o sublime, como palavra erguida e dignificada, costuma a excluir, pelo próprio privilégio dado à palavra, o corpo que a engendra. Nosso interesse aqui é explorar o texto para além do biografismo de "quem é o autor", vez que há muito esta noção foi abalada pela sua insuficiência, o foco da discussão é pensar quem escreve em sua dimensão subjetiva na qual se cruzam a escrita e outras dimensões de vivência e estas, com certeza, passam pelo corpo e pelas experiências derivadas de viver neste espaço bio-fisiológico. Se existe, inclusive como campo de estudo, uma ciência e lógica do corpo, a produção escrita igualmente o atravessa. 
Alguns textos encenam estas questões como estratégia de política de representação, como o Cuti, em Quebranto:

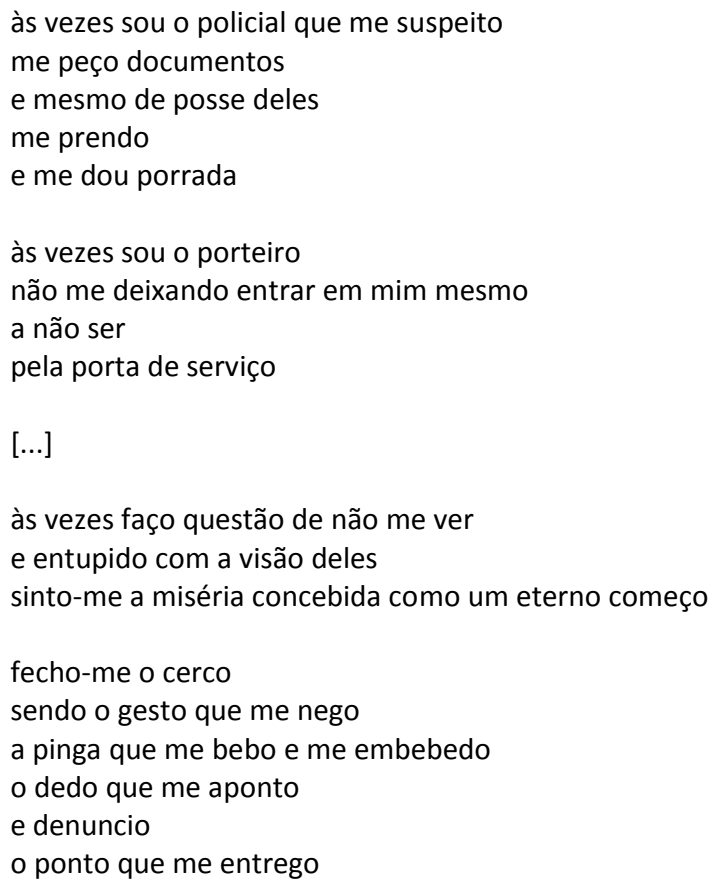

às vezes...

Neste poema, o corpo é a via produtora das relações e reações sujeito-mundo, mundo-sujeito e, introjetando a violência do estereótipo (BHABHA, 1998) impõe-se as condenações mais brutas como um narciso diante de um espelho negativo. Num outro sentido, subvertendo as práticas de submissão e reinventando, pelo caminho da ironia as relações homemmulher, Elisa Lucinda avisa: "Moço, cuidado com ela. / Há de se ter cautela / com esta gente que menstrua".

Em contrapartida a este movimento, o que se vê é o recrudescimento das fronteiras epistemológicas. Assim como a psicanálise apropriou-se do discurso desprovido de um corpo onde este se encenasse franqueando este último à psicanálise e à medicina, como afirma (BIRMAN, 2001), o campo da Teoria da Literatura estuda do texto em seu já conhecido estatuto de beleza, de apuro estético, o puro texto, sem sangue de entranhas. O texto só, 
sem o excesso dos sobrenomes que podem ser atribuídos à literatura. No investimento pretensamente libertário da literatura como sendo uma entidade que sobre as outras se eleva, uma grande mãe universal; inculca-se a negação da partilha do terreno da escrita entre aqueles que dela se apossam e este movimento apenas reedita a negação da diferença que, eternamente, bate à porta do cânone.

Com isto interessa dizer que sim, a literatura tem sobrenomes, e são muitos: homoafetiva, feminina, negra, periférica, oral. Cada um deles engendra um campo de diferenças constantemente silenciadas e caminham na contra mão, pela afirmação da diferença e negação da identidade unívoca uma vez que ela corresponde àquele que se pensa como o neutro, o apaziguador, o não-marcado que, ao fim e ao cabo, nada mais é que uma simulação de presença pura, igual a si mesmo que só admite ladear-se de outros objetos narcisicamente interiorizados, literaturas sem marcas, sem sobrenomes, mas com nomes próprios potentes o suficiente para solapar qualquer diferença. Assim, defendemos a força não essencializante dos sobrenomes como incidentes ou acontecimentos literários que não aprisionam a leitura a um condicionamento limitado e imediatista, uma vez que não devem ser pensados como novos centramentos fixos, como outras formas de apagamento da diferença, mas como centros instáveis e inseguros que preservam a capacidade que toda expressão artística tem de se oferecer ao mundo em ininterrupto devir. Na cena da possibilidade pura, a nomeação deseja mais abrir um flanco para o exercício das diferenças radicais, para a exposição das subjetivas como clave possível de leitura de mundo.

\section{POÉTICAS DA SUBALTERNIDADE E ESTÉTICAS DA DIFERENÇA}

Gayatri Spivak, em seu texto Pode um subalterno falar (2010), dedicase a, apontando uma limitação na posição de Gilles Deleuze e Michel Foucault acerca da representação do Outro enquanto Sujeito descentrado, denunciar que o subalterno não consegue falar por que ele é sistematicamente não silenciado, mas falado pelo outro. Hommi Bhabha nos apontou a formulação básica desta problemática ao discutir o estereótipo como sendo uma estrutura calcada numa verdade não verificável, na medida em que ela se repete, assegurando seu lugar e valor de verdade, mas jamais se expondo à verificação empírica, sob o risco de provar-se falso ou insuficiente para dar conta desta alteridade. Por seu turno, Spivak insere a noção de "sujeitos-efeitos" afirmando que os sujeitos pensados como subalterno são efei- 
tos do discurso que assim os representa. Tomando como foco de análise o ritual de imolação da viúva hindu diante da pira onde arde o corpo do marido morto, ela analisa a formulação da subalternidade destas mulheres pelo discurso imperialista britânico que, a fim de salvá-las de um pretenso condicionamento ou de um compulsório suicídio simplesmente proibiu estas mulheres de vivenciarem o "sacrifício da viúva" como formas de salvá-las de uma subjugação pelo masculino, o que foi equacionado por Spivak como sendo: "homens brancos salvando mulheres de pele escura de homens de pele escura". Neste sentido, o ímpeto salvador e libertário do colonizador britânico deixa escapar que, na dinâmica das relações do ritual das mulheres santi a imolação era uma escolha, não uma obrigação. Giorgio Agamben num recente texto (2011), ao discutir o conceito filosófico potência aqui comparece no sentido de nos fazer compreender que o que é retirado destas viúvas com a liberdade a elas impingida é a possibilidade de vivenciar em plenitude a potência do ser viúva, na medida em que este conceito, trazido de Aristóteles por Agamben pressupõe que toda potência traz consigo a possibilidade da não-potência que, simplificando, pode ser compreendido como sendo a vivência ou não da prática possibilitada pela potência: poder ser uma viúva santi é poder deliberar sobre sua vontade de seguir o marido e imolar-se diante da pira ou virar as costas à morte do outro e continuar vivendo, segundo Spivak (2010, p. 104): “Obviamente não estou advogando a matança de viúvas. [...] No caso da autoimolação das viúvas, o ritual não está sendo redefinido como uma superstição, mas como um cri$m e^{\prime \prime}$.

O discurso colonial se arvora a representar a mulher, falar por ela e protegê-la, sem, no entanto, estar interessado em ouvi-la. A vitimização apriorística das mulheres santi apenas reforça a sua posição subalterna através de uma força que irá salvá-las e libertá-las. Este mesmo discurso de aplica de maneira veemente, segundo Franz Fanon (2008), sobre os corpos nos negros que são, no discurso paternalista etnocêntrico, infantilizados e tratados como crianças desorientadas ou como sujeitos desprovidos de juízo de valor e consciência. Os negros costumam a ser divertidos.

Talvez seja por isto que, dentre as missões primeiras da formação de um discurso identitário afrodescendente, Franz Fanon aponte, como pedra de toque aquilo que ele nomeou de descolonização das mentes. Este processo passa pela assunção de um lugar de fala compreendendo as limitações e estereótipos que repousam sobre estes sujeitos e investindo em subvertê-los. Segundo Osmundo Pinho (2007 [online]): 
A descolonização intelectual como etapa da emancipação racial e conseqüente transformação da sociedade como um todo deverá, desse modo, passar pela ação intelectual contra-hegemônica. A emergência de uma crítica subalterna representa assim o trabalho de formação de intelectuais subalternos.

Neste ensejo, explorações subalternas dos campos de conhecimento podem ser potentes na contribuição para a ampliação e até um reagendamento das prioridades ensejadas por algumas práticas. Pensamos aqui o subalterno como sendo um discurso que circula numa via alternativa, subterrânea e, quiçá, obedecendo à lógica das tocas dos ratos conforme pensada por Deleuze em Mil platôs, rizomática.

A acintosa ausência de mulheres negras no cânone literário brasileiro pode ser justificada mais pelos processos de invisibilização e minoração do valor estético de seus textos que por qualquer questão relativa à sua potência criadora. A intensa produção de literatura por escritoras como Maria Firmina dos Reis, Auta de Souza, Carolina Maria de Jesus até as contemporâneas: Conceição Evaristo, Miriam Alves, Geni Guimarães, Lia Vieira, Esmeralda Ribeiro e as mais jovens Cristiane Sobral e Mel Adún confirma que a escrita afro-feminina foi freqüente. Estas mulheres que são jornalistas, como Mel Aún e Esmeralda Ribeiro; doutoras em Literatura como Conceição Evaristo e Míriam Alves; Pedagogas como Lia Vieira; atrizes como Cristiane Sobral e, ainda, escritoras nacionalmente premiadas como o caso de Geni Guimarães com o Jabuti/1990 com o livro A cor da ternura têm seus escritor apenas muito recentemente estudados, mas ainda há uma grande lacuna nos estudos no que diz respeito à dimensão estética que estes escritos propõem.

Em recente conversa com Conceição Evaristo, pude discutir com ela acerca desta demanda e confirmar uma hipótese de estudo que me perseguia, a saber, a idéia de que os instrumentais e paradigmas de análise que comumente são acionados nos estudos de literatura não seriam suficientes para abarcar a complexidade das representações e das opções éticas e estéticas oferecidas pelos textos destas mulheres, esta questão foi trazida por Florentina Souza Santos (2005) quando esta se dedicou a analisar as representações da afrodescendência nos Cadernos Negros e no Jornal do MNU. Avançando no sentido de melhor enxergar a complexidade da questão, nos centramos sobre a escrita de mulheres negras tentando comprovar que o próprio texto construído por elas traz, no seu corpo, sinais de uma possível teorização sobre eles, uma vez que são muito intensas as reflexões sobre o 
percurso criativo e a formulação subjetiva e estas são ratificadas de maneira intensa em entrevistas, conferências e depoimentos cedidos por elas.

A construção da diç̧ão estética destas escritas passa pelo estabelecimento de prioridades éticas e políticas que constam na agenda do dia de muitas mulheres negras brasileiras.

Desta forma, os temas mais recorrentes passeiam pela emancipação do lugar da mulher negra como objeto de usufruto do homem pelo sexo, através de uma assunção do domínio de seu próprio corpo em sua vivência sexual, como se vê em Instante Mulher, de Mel Adún:

Com vontade apenas de boas risadas

Do carinho descarado embaixo

De qualquer lençol que me abrigue

Sem brigas

Não tenho intimidade pra brigar com você.

Exijo as boas trepadas seguidas deuteamos falsos

Com prazer dou risada das suas piadas

Se não me agradam não te permito repetir o prato

Estou nesse estágio - posso escolher

Pode falar bobagens, sentir prazer quando te molho,

Posso até bater, mas ainda não aprendi a apanhar...

Outra questão acionada é a relação com o homem em sua absoluta maioria negro, e que, muitas vezes, deseja subjugá-las, como se vê nos versos de Mel Adún:

Não vou mais lavar os pratos,

Agradeço a Sobral

Vou ser agora meu bem, viu meu mal?

Cansei de ser você: de sonhar seus chatos sonhos

Cansei de me emperiquitar

Para encontros enfadonhos.

Agora serei meu bem,

Vou reaprender a deitar

E sonhar sonhos meus

Com as minhas cores prediletas.

Sem pensar em sentar de pernas cruzadas

Sem ligar pra depilar

Não quero baile de debutantes,

Tampouco ter filhos ou casar.

Agora vou ser meu bem, viu meu mal?

No seu texto, Adún cita um já clássico poema de Cristiane Sobral chamado "Não vou mais lavar os pratos" que aciona outro tema recorrente: 
a emancipação da mulher não pelo trabalho, uma vez que este já fazia parte do cotidiano da mulher negra no Brasil desde a escravização, mas pelo acesso ao estudo. Basta lembrar o que demonstram os últimos números da educação no Brasil no que tange às populações afrodescendentes:

Não vou mais lavar os pratos.

Nem limpar a poeira dos móveis.

Sinto muito. Comecei a ler.

Abri outro dia um livro e uma semana depois decidi.

Não levo mais o lixo para a lixeira.

Nem arrumo mais a bagunça das folhas no quintal.

Sinto muito. Depois de ler percebi a estética dos pratos,

a estética dos traços, a ética,

\section{A estática}

Olho minhas mãos quando mudam a página dos livros,

Mãos bem mais macias que antes,

E sinto que posso começar a ser a todo instante.

Sinto.

As temáticas relativas às religiões de Matriz Africana igualmente comparecerão, tanto para inserir no discurso poético outra cosmogonia, que não a cristã-católica, como forma de mediação para a reflexão de questões que atravessam as vivências das populações negras como o extermínio dos jovens seja pela violência policial, seja pelas drogas, a história dos quilombolas, as representações heróicas ou mesmo a inclusão das demandas relativas à homoafetividade, como se vê neste poema de Esmeralda Ribeiro:

\section{AOBOBOÍ! OXUMARÉ}

Deusa do povo jeje

Festeje a dupla existência do ator,

Que encena a realidade arco-íris,

Colorindo o palco da vida.

Entre idas e vindas,

O cenário humano expõe,

Metade que menstrua, metade masculina.

Na camarinha dos orixás

Em movimentos cíclicos,

Oxumaré dança pro céu, dança pra terra,

Levando as águas daqueles que são,

Ao mesmo tempo, homem e mulher. 


\title{
Aoboboí!! Oxumaré
}

Ensina homens e mulheres que o outro,

Gostemos ou não,

Quando cerram-se as cortinas,

Encena sua real paixão.

\section{Aoboboí!! Oxumaré}

Como elemento simbólico que representa as múltiplas possibilidades de ser de Oxumaré, o arco-íris, mera simulação, mero efeito óptico, em si múltiplo em cores e duplo por trazer consigo sempre uma sombra colorida, mimetiza a potência do ser homossexual pelo movimento contínuo de escape às limitações dicotômicas das sociedades patriarcais. Tal como o arcoíris esta identidade não está jamais onde aparenta estar.

Obedecendo à dinâmica das relações nas religiões de Matriz africana, donde as ações e percepções das divindades não se reservam apenas ao mundo material tendo uma intrusão permanente na vivência material e cotidiana dos sujeitos, no poema "Sálùba" Esmeralda Ribeiro traz, através da figura da grande mãe da transmutação, Nanã, um apelo em favor da vida jovens afrodescendentes que faz com que a sua voz se faça em plena interação com o movimento contra o extermínio destes jovens nas periferias de Salvador-BA chamado "Reaja ou será morto; reaja sou será morta". O poema evoca o perfil materno, mas emancipa a ação da maternidade do puro ato gerador de vida para ser pensado como força que engendra a capacidade de proteger, defender e guardar estes sujeitos do mal que vive nos becos mais estreitos do Pelourinho, na acintosa claridade nebulosa da crackolândia e na infinidade de olhos obsedados pelo embotamento da droga. Assim a questão se apresenta no poema:

\section{SÁLÙBA}

\author{
Nanã Buruku \\ Divindade do povo Ashantí \\ embala com dignidade \\ àqueles de tez escura \\ jogados em qualquer vala dura \\ na lua sua banhe com altivez os corpos \\ daqueles sem rosto na multidão.
}

Sálùba

Divina mãe

leva prolago dos segredos 
encantados das avenidas

na brincadeira violenta da rua

o enredo termina em nó atado

nem minha, nem tuas sitiadas crianças.

Ancestral mãe revela pro mundo

porque há presentes letais:

cola, crack, outros tantos mais ofertados

para aqueles de tez escura

cuja figura é contornada pela lâmina

afiada do desprezo.

Afetuosa mãe, cuida desses filhos

que não são seus

agora, grandiosa mãe

só você zela em cerimônia secreta

corpos esquecidos que repousam

na fria cama do asfalto.

As qualidades do Orisá Nanã - aquela que mora na lama e tem a transmutação de energia, na passagem da vida para a morte o seu campo de ação - aparecem como forma de reinterpretação da maternidade. Como quem molda os corpos de lama cabe, ao Orisá oferecer a sua generosidade aos sujeitos desubjetivados pelas leituras minoradas de suas diferenças e necessidades que se fazem na cotidianidade das ruas, nas multidões. A altivez, advinda dos poderes que possui e dos modos de relacionamento com a vida e a morte, em nada se aninha com o pesado passo e com o corpo encurvado da divindade anciã quando manifestada. A fragilidade do corpo que se curva numa dobre sobre si mesmo, é facilmente desmentida quando recordamos o respeito e, por vezes, temor que esta mãe que nos faz nascer às avessas pode provocar. Obedecendo à lógica da ancestralidade, a sabedoria e o poder mágico de Nanã dão a ela, juntamente com a sua postura diante do mundo, uma altivez que representa a sua personalidade e, pelo lugar que ocupa, pode cindir co cordão que puxa os jovens para a morte:

Ancestral mãe revela pro mundo

porque há presentes letais:

cola, crack, outros tantos mais ofertados

para aqueles de tez escura

cuja figura é contornada pela lâmina

afiada do desprezo. 
A maioria dos Orisás femininos traz, no seu campo de ação simbólica, a fluidez , a exemplo das águas e dos ventos, Nanã, na lama que se arrasta, representa uma maternidade bruta, que faz assentar a flutuação das possibilidades. E isto aparecerá no poema como um recurso último para interromper a via que conduz os jovens diretamente ao ocaso. O apelo a Nanã emerge, então, na ante-sala da morte: vala dura, multidão, avenidas onde as crianças encontram-se sitiadas e onde a vida parece ser um nó infinito.

Ainda no âmbito dos mistérios e representando o tempo atemporal dos ciclos femininos da lua, dos mares e dos rios que alegorizam os próprios ciclos do corpo feminino, o sangue menstrual, o aleitamento, os gozos e desejos do corpo, narrando os gestos, reações e vivências como ritos a poesia da angolana Ana Paula Tavares traça uma subjetividade marcada, preenchida, feminina, mas num sentido mais amplo:

É muito recente este fenômeno de haver uma consciência do "eu feminino" e uma tentativa de reivindicar este espaço que ele comporta. Mas também não podemos interpretar, mesmo em relação às novas tendências, mesmo em relação às coisas que surgiram há pouco tempo, não podemos interpretar isto como uma poesia de gênero. Digamos que algumas mulheres, sobretudo a partir dos anos 80, começaram a deslocar o centro onde o sujeito poético estava muito fincado. Então, há uma poesia que surge falando da problemática de ser mulher numa sociedade africana como a nossa (TAVARES, 2000).

Ao se afastar de uma escrita de gênero, Tavares propõe um deslocamento, inclusive, no conhecimento eurocentrado de gênero. A defesa aqui é de uma escrita feminina no sentido de que traz, para a cena da lírica, o universo da mulher não apenas como tema, mas como opção estética, como uma espécie de gramática poética.

Cerimônia de Passagem

Ana Paula Tavares, Dizes-me coisas amargas como os frutos.
"a zebra feriu-se na pedra
a pedra produziu lume"
a rapariga provou o sangue
o sangue deu fruto
a mulher semeou o campo
o campo amadureceu o vinho
o homem bebeu o vinho
o vinho cresceu o canto 
o velho começou o círculo

o círculo fechou o princípio

"a zebra feriu-se na pedra

a pedra produziu lume"

Luanda, 85

A cena da cerimônia começa e se fecha com um mistério, este, aliás, atravessará toda a mítica e a mística africana vindo, nas Religiões de Matriz Africana, ensejar o lugar do segredo como um espaço definitivo do poder: num terreiro nada se pergunta, se aprende. Assim, a zebra que se feriu na pedra recupera a importância do sangue nos rituais e este, como partícula metafísica do corpo feminino, como parte integrante do ciclo, se destransforma de sangue em lume, em luz. Diferente de uma leitura de matriz cristã, que apontaria para uma redenção pelo sofrimento, o sangue que brota da zebra é sangue, mas é também uma outra coisa, e, esta outra coisa é a alegoria, imagem-base da cultura africana.

Este mesmo sangue com seu poder de lume converte a rapariga na mulher, numa possível referência ao sangue da menarca - primeira menstruação - ou o sangue, também iniciático, do desvirginamento ou do parto. O campo em "a mulher semeou o campo / o campo amadureceu o vinho" pode ser lido como o corpo fértil que, dentro de si, amadurece - no tempo mais certo - não a uva, mas já o vinho, elemento desorganizador de uma ordem, acesso à via imaginária, à embriaguez. Apenas aí aparece o homem, bebendo do vinho, cantando seu canto e o velho começando o círculo que, por si, acha o seu princípio. Aqui o que se vê é uma delimitação de espaços: o interno, do feminino; e o externo, que canta, que tem mãos para riscar o círculo, do masculino. Entretanto, sem a ordem interiorizada do ritual da mulher, nada poderia ser posto à circular. Nisto, a poesia representa a maneira patriarcal de divisão do trabalho:

De um lado os homens, a quem as civilizações atribuem os trabalhos voltados para o lado do exterior, do oficial, do público, do direito, do alto, do descontínuo [...] Por exemplo, alimentar os animais, levar o rebanho ao pasto, cultivar os campos, arar a terra, semear, [...] Às mulheres competem os afazeres classificados como fazendo parte do lado interior, úmido, baixo, contínuo, por isso lhes são atribuídos todos os trabalhos domésticos, isto é, os trabalhos privados e escondidos e até mesmo invisíveis ou vergonhosos, os mais sujos, monótonos, penosos e humildes. Por exemplo: cozinhar, criar e 
alimentar as crianças, os animais, varrer, tecer, moer, ordenhar, transportar água, amassar o barro (BOURDIEU, 1995, p. 113).

Outra imagem que aparecerá com alguma freqüência na poesia de Paula Tavares é a da mãe. Diferente da metáfora já gasta articulada por muitos poetas dos dois lados do atlântico da África-mãe, a maternidade aqui é vivenciada pelo viés da cumplicidade, da convivência estreita de dois sujeitos submissos a um mesmo espaço subjetivo. Se a mulher não encontra em outros lugares a chance de sua escuta amorosa e atenta, é no espeIhamento narcísico entre mulheres, sempre orbitando pela circularidade mãe-filha, independente de assim o serem, que formará uma cadeia de aproximações sutis e afetivas.

A leitura mais atenta logo perceberá nestes textos uma capacidade absolutamente feminina - posto que feita nos escuros e úmidos, engendrada no útero e nas entranhas. Aqui, o estético é ético, o poético é político, entretanto, não falamos aqui do universo de trincheiras e de guerras exteriores e masculinas, a cena da luta que aqui se apresenta é aquela travada nos baixos e sombrios lugares onde dormem os mais poderosos silenciamentos, onde o corpo guarda para si, e fala em linguagem esquecida, a história dos menos importantes que é a sua própria história, para os que tenham ouvidos de lhes ouvir.

Instauram-se, então outras tradições e fundam-se outros modos de representar as relações, dentre as que sofrem a mais intensa reencenação, estará aquela estabelecida entre homens e mulheres. Mel Adún no poema Homem nobre dedica-se e rever os padrões que sustentam estas relações:

Homem Nobre

A tarde cai e com ela não ficamos mais vazios;

sou inteira e parte do nobre guerreiro.

Com ele tudo está sempre certo, mesmo que por vezes eu sinta algo de errado.

Meu guerreiro com sua ilustre lança

me lança um olhar certeiro

que me alcança

e com a negreza e gentileza dos seus,

afasta qualquer mau pensamento.

A tarde cai e com ela

não caem mais minhas esperanças,

não me sinto só

com o apagar crucial das luzes.

Espero a noite cheirosa

debaixo de um lençol fino

120 Número temático: Literatura, cultura e memória negra. A Cor das Letras - UEFS, n. 12, 2011 
que me aquece por tempo determinado,

até o meu nobre voltar.

Ao negar entregar-se ao desamparo que é a chegada da noite para a mulher que espera, o eu-lírico reforça a onipresença do ser amado não pela sua mera palavra de promessa lançada ao vazio, pelo desamparo que o sujeito poético possa vir a sentir, mas pela própria inteireza que esta voz feminina apresenta quando afirma que a queda da tarde não a deixa frágil ou desamparada. Os seres amados imantam-se numa simbiose complexa que se confirma num paradoxo: "sou inteira e parte do nobre guerreiro".

Ser "parte" do nobre guerreiro, do ser amado nada tira, em força ou plenitude ao feminino, ela não se inferioriza. A força dele se faz compartiIhar de uma mulher que se sabe plena. Neste sentido, subverte-se o mais elementar dos estereótipos femininos, o da castração que, por seu turno, configura e determina a sua minoração perante o homem, detentor do falo, pleno a si mesmo. A vagina é socialmente pensada não apenas como o símbolo da vulnerabilidade feminina pelo sangue menstrual e pela possibilidade de engravidar fora de hora - questão largamente retomada por inúmeras narrativas, desde os contos de fada, por exemplo. Ela também representa a fenda estreita que limita a sua visão e vivência de mundo.

$\mathrm{Na}$ esteira da rearrumação da cena dos afetos mulher-homem, subvertendo inclusive o pólo ordenador de tal eixo, fresta vira festa, vira potência de negação, reescrita e ação interventiva sobre o mundo de forma que é no contexto da escrita, no corpo da letra, que o sujeito finalmente se representa como diferença radical e inconciliável, emerge, tal como o simulacro deleuziano, enquanto não mais representação correspondente e apaziguadora, mas enquanto apresentação de outra forma de inserção no mundo. A palavra, objeto antes pensado como meramente estético, dinamiza o seu campo de ação e submetendo-se à força plástica que, num mesmo gesto, desloca de seu lugar as narrativas anteriores sobre o feminino e constrói uma nova fala e um novo modo de falar.

\section{CONSIDERAÇÕES FINAIS}

Na poesia, espaço onde se construiu tradicionalmente uma representação do feminino pelo masculino na imagem da santa, da puta, da amada, desejada, desprezada ou inalcançável mulher, insere-se a rasura fundante de outro modus fasciende que passa, conforme apontou Florentina Santos, 
por uma proposta estética diferenciada que é insubmissa ao cânone do que se convencionou chamar de belo em literatura.

A proposta estética oferecida pro estes textos tem algumas similaridades. Uma das marcas mais fortes é o abrandamento das alegorias, figuras de imagem calcadas na comparação complexa, em favor das metáforas, símiles, catacreses, assonâncias, aliterações e ironia. As imagens construídas se propõem a construir uma leitura possível do mundo, tornando-o condizente com o olhar diferenciado que sobre ele se lança. Desta forma, há um progressivo abandono das formas de representação já desgastadas pelo uso em favor de pessoalisar, pela diferença mesmo, pela différ (DERRIDA), a dicção da escrita. As mensagens engendram um sentimento de limite, de exaustão, de alcance do limite do tolerável e da inviabilidade da manutenção das relações entre os arquétipos femininos e masculinos. Os textos trazem a reivindicação do reconhecimento de sua completude pela negação da castração e rechaçamento da idéia rebaixadora de inveja do falo, o que se faz acompanhar de uma assunção libertadora do gozo e do prazer sexual.

Não obstante, temas que percorrem o discurso poético de inúmeros escritores também comparecerão revisitados nestes poemas, a exemplo do recorrente tema do fazer poético, como se vê em "Da calma e do silêncio", de Conceição Evaristo:

Quando eu morder

a palavra,

por favor

não me apressem,

quero mascar,

rasgar entre os dentes,

a pele, os ossos, o tutano

do verbo,

para assim versejar

o âmago das coisas.

Quando meu olhar

se perder no nada,

por favor,

não me despertem,

quero reter,

no adentro da íris,

a menor sombra,

do ínfimo movimento. 


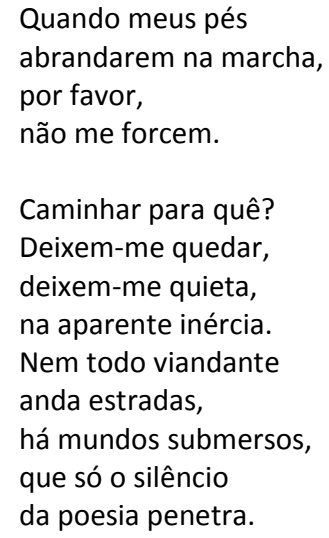

Esta produção poética, desta forma, instaura como demanda a capacidade de acionar leituras diferenciais que busquem perceber, na recorrência de elementos como a substituição da alegoria ou da metáfora pela comparação simples; nas ironias; no privilégio de versos livros e brancos; na construção de desenhos poéticos na página e nas outras formas de reescritas das histórias de si, a construção de uma personalidade poética não submissa ao cânone que jamais se interessou por abrigá-las.

\section{REFERÊNCIAS}

AGAMBEN, Giorgio. A potência do pensamento. Revista do Departamento de psicologia da UFF. Disponível em: www. Scielo.br. Acesso em: 30 ago. 2011. [online].

BARTHES, Roland. Aula. Trad. Leyla Perrone-Moisés. São Paulo: Cultrix, 1988.

BHABHA, Homi K. O local da cultura. Belo Horizonte: UFMG, 1998.

BIRMAN, Joel. Mal-estar na atualidade: a psicanálise e as novas formas de subjetivação. 3. ed. Rio de Janeiro: Civ. Brasileira, 2001.

BOURDIEU, Pierre. Uma imagem ampliada. In: Idem. A dominação masculina. Trad. Maria Helena kühner. Rio de Janeiro; Bertand Brasil, 2007.

CUTI. Quebranto. In: Idem. Negroesia. Belo Horizonte: Mazza Edições, 2007, p. 53-54.

DELEUZE, Gilles; GUATARRI, Félix. Mil platôs - capitalismo e esquizofrenia. Trad. Aurélio Neto e Celia Costa. Rio de Janeiro: Ed. 34, 1995.

DELEUZE, Gilles. Platão e o simulacro. In: Idem. Lógica do sentido. 4. ed. São Paulo: Perspectiva, 2000.

DERRIDA, Jacques. A escritura e a diferença. Trad. Maria Beatriz Marques Nizza da Silva. São Paulo: Perspectiva, 2002. Col. Debates.

DERRIDA, Jacques. A farmácia de Platão. Trad. Rogério da Costa. São Paulo: Iluminuras, 2005. 
FOUCAULT, Michel. 1967 - Nietzsche, Freud, Marx. In: Idem. A arqueologia das ciências e História dos sistemas de pensamento. Org. Manoel Barros A. Motta. Trad. Elisa Monteiro. Rio de Janeiro: Forense Universitária, 2005.

FOUCAULT, Michel. A Ordem do discurso. Trad. Laura Sampaio.São Paulo: Loyola, 1998. (Leituras Filosóficas; 4).

FOUCAULT, Michel. As regularidades discursivas. In: Idem. A arqueologia do saber. Trad. Luiz Felipe Neves. Rio de Janeiro: Forense Universitária, 2000.

FOUCAULT, Michel. Nascimento da biopolítica. São Paulo: Martins Fontes, 2008.

FOUCAULT, Michel. O que é o autor? Lisboa: Veja, 1992.

FANON, Franz. Peles negras, máscaras brancas. Salvador: Edufba, 2008.

FREUD, Sigmund. Projeto para uma psicologia científica - 1895, v. 1. In: Idem. Publicações pré-psicanalíticas e esboços inéditos. Edição Standart Brasileira das Obras Psicológicas Completas de Sigmund Freud. Rio de Janeiro: Imago, 1969.

HALL, Stuart. Estudos Culturais e seu legato teórico. In: Idem. Da diáspora: identidades e mediações culturais. Belo Horizonte: UFMG, 2003.

HALL, Stuart. Nascimento e morte do sujeito moderno. In: Idem. A identidade cultural na pós-modernidade. Trad. Tomaz Tadeu da Silva e Guacira Lopes Louro. Rio de Janeiro: DP\&A, 1999.

HUYSSEN, Andréas. Mapeando o pós-moderno. In: HOLANDA, Heloisa B. (Org.). Pósmodernismo e política. Rio de Janeiro: Rocco, 1992.

NIETZSCHE, Friedrich. Segunda consideração intempestiva: da utilidade e desvantagem da história para a vida. Trad. Marcos Casanova. Rio de Janeiro: Relume Dumará, 2003. Col. Conexões, 20.

PADILHA, Maria Cavalcanti. Novas fiandeiras das palavras. In: Idem. Novos pactos, outras ficções: ensaios sobre literaturas afro-luso-brasileiras. Porto Alegre: EDIPUCRS, 2002. Col. Memória das Letras, 10.

PINHO, Osmundo. Lutas culturais: relações raciais, antropologia e política no Brasil. Revista de Sociedade e Cultura, v. 10, n. 1, p. 81-94, jan./jun. 2007. Disponível em: www.scribd.com. Acesso em: 30 ago. 2011. [online].

SOUZA, Florentina Silva. Afro-descendência em Cadernos Negros e Jornal do MNU. Belo Horizonte: Autêntica, 2005. 